\title{
Maamme lääkäritilanteesta \\ ja toimenpiteistä sen \\ parantamiseksi
}

\author{
Pääjohtaja NIILO PESONEN \\ Lääkintöhallitus
}

Jonkin maan lääkäritarpeen yksityiskohtainen määrittäminen ei ole helppo tehtävä. On hyvin ymmärrettävää, että yleisesti hyväksyttyä menetelmää, jota siinä suhteessa voitaisiin käyttää, ei ole esitetty. Kaikki ne laskelmat, joita tähän asti on käytetty ja jotka perustuvat eri lääkintähuollon alojen tarpeen yksityiskohtaiseen arviointiin, ovat osoittautuneet epäonnistuneiksi. Jos maan lääkäritarvetta laskettaessa otetaan huomioon vain jo perustetut ja lähitulevaisuudessa perustettaviksi suunnitellut virat, jää arviointi peräti yksipuoliseksi ja johtaa vääriin tuloksiin. Niin on käynyt meillä samoin kuin muuallakin maailmassa, missä laskelmia on tältä pohjalta suoritettu. Perusvirheenä niissä on otaksuma, että jos koulutettujen lääkärien määrä on niin suuri, että kaikki lääkintähuollon eri aloilla olevat ja lähiaikoina perustettaviksi suunnitellut lääkärinvirat saadaan täytetyiksi, ei lääkäripulaa synny; ikäänkuin lääkintähuollon mitä erilaatuisimpien palvelusten kysyntä olisi tyydytettävissä vain virkoja perustamalla. Samalla on jätetty kokonaan ottamatta huomioon yhteiskunnan rakenteessa, sosiaalisessa lainsäädännössä sekä väestön sivistystasossa ja varallisuudessa tapahtuvat muutokset. Lääketieteen, sairaanhoidon ja terveydenhoidon kehitys on niissä niinikään unohdettu. Ja kuitenkin nämä ovat juuri niitä tekijöitä, jotka erittäin suuressa määrin vaikuttavat kunkin maan lääkäritarpeeseen.

Esimerkkinä siitä, miten karkeasti voidaan erehtyä, jos edellä mainittua menettelyä lääkäritarvetta laskettaessa nouda- tetaan, huomioonottamatta viimeksi mainittuja näkökohtia, voidaan mainita Suomen Lääkärilehdessä sekä suomen- että ruotsinkielisenä vuonna 1950 julkaistu tutkielma »Suomen lääkäritilanne vuoden 1950 alussa sekä lähivuosikymmenien lääkäritarpeesta». Tuossa tutkimuksessa päädytään siihen tulokseen, että meillä nyt kymmenen vuoden kuluttua tutkimuksen ajankohdasta ei enää olisikaan lääkäreistä puutetta, vaan että meillä pikemminkin olisi liikaa lääkäreitä. »Nykyinen valmistuvien lukumäärä on ilmeisesti riittävä lähivuosikymmenen tarpeen tyydyttämiseksi», sanoo tutkimuksen tekijä vuonna 1950. Julkaisun ruotsintaja on ollut asiasta vieläkin vakuuttuneempi, koskapa hän on kääntänyt sanat »ilmeisesti riittävä» sanoilla »säkert tillräckligt» (varmasti riittävä)! Kun meillä tällä hetkellä, siis juuri edellä mainitussa tutkimuksessa kosketeltuna ajankohtana, lääkäripula on kipeimpiä lääkintähuollollisia probleemojamme, osoittaa se, miten edellä mainittu arviointitapa on johtanut harhaan. Olen maininnut näistä tutkimuksista siksi, että vieläkin saattaa kuulla ajatuksia siitä, että todellisen lääkäritarpeen arvioiminen olisi suoritettava edellä mainittua menettelytapaa käyttäen.

Ruotsissa on aivan äskettäin ilmestynyt komiteanmietintö »Om läkarbehov och läkartillgång» (Statens offentliga utredningar 1961: 8, Stockholm 1961), jossa koetetaan selvittää Ruotsin lääkäritarve vuoteen 1980 mennessä. Tässä tutkimuksessa on pyritty mahdollisimman perusteellisesti ottamaan huomioon kaikki ne tekijät, joi- 
Taulu 1. Lääkäritiheys eräissä maissa 1950-luvun lopulla.

\begin{tabular}{|l|l|r|}
\hline Vuosi & \multicolumn{1}{|c|}{ Valtio } & $\begin{array}{r}\text { Asukkaita } \\
\text { yhtä lääkä- } \\
\text { riä kohden }\end{array}$ \\
\hline 1958 & Neuvostoliitto & 601 \\
1958 & Itävalta & 607 \\
1958 & Tšekkoslovakia & 615 \\
1958 & Sveitsi & 688 \\
1958 & Länsi-Saksa & 725 \\
1959 & Tanska & 750 \\
1958 & USA & 790 \\
1958 & Uusi Seelanti & 796 \\
1958 & Belgia & 835 \\
1956 & Norja & 850 \\
1956 & Australia & 854 \\
1958 & Hollanti & 880 \\
1958 & Englanti ja Wales & 900 \\
1960 & Ruotsi & 1060 \\
1960 & Suomi & 1527 \\
\hline
\end{tabular}

den on arveltu voivan tavalla tai toisella vaikuttaa lääkäritarpeeseen. Komitea tulee siihen tulokseen, että vuonna 1980 tarvittaisiin Ruotsissa 15 000-16000 lääkäriä, mikä merkitsisi sitä, että maassa tulisi silloin olemaan noin 1 lääkäri 550 asukasta kohti. Komitean arvioima tarve ylittää runsaasti useimmissa maissa vallitsevan tilanteen. Se merkitsee Ruotsin osalta nykyisen lääkärimäärän runsasta kaksinkertaistumista.

Suomessa oli vuoden 1960 lopussa 2915 lääkäriä, joista tosin 88 oli ulkomailla. Suhteessa asukasmäärään meillä oli tuona ajankohtana 1 lääkäri 1527 asukasta kohden. Millainen vastaava tilanne on muissa maissa, ilmenee oheisesta taulukosta (taulu 1). Niinkuin taulukosta näkyy, oli Skandinavian maista Norjassa 1 lääkäri 850 asukasta kohden ja Tanskassa 1 lääkäri 750 asukasta kohden. Ruotsissa oli sanottuna ajankohtana 1 lääkäri noin 1060 asukasta kohden. Taulukossa esitettyjä lukuja arvosteltaessa on otettava huomioon eri maissa vallitsevat erilaiset olosuhteet, mm. muun sairaanhoitohenkilökunnan käyttömahdollisuudet, sairaanhoitohenki- lökunnan koulutuksen taso yms. seikat. Mutta joka tapauksessa vertailusta käy erittäin selvästi ilmi, että meidän maassamme on lääkäritiheys huonompi kuin missään taulukossa mainituista maista. Kuvaavaa tilanteelle muissa Skandinavian maissa on, että sekä Norjassa että Tanskassa lääkintäviranomaisten käsityksen mukaan ei vallitse lääkäreiden ylituotantoa, vaan kaikille lääkäreille riittää työtä. Jos edellä olevien lukujen perusteella haluaa vetää jonkinlaisia johtopäätöksiä meidän lääkäritarpeestamme ja jos otetaan huomioon, että meilläkin lähitulevaisuudessa toteutetaan sairausvakuutusjärjestelmä, voisi lähinnä asettaa tavoitteeksi Tanskan olosuhteet. Ruotsin lääkintäviranomaiset kamppailevat parhaillaan lääkäripulan kimpussa.

Miltä sitten näyttävät meidän mahdollisuutemme lääkäritilanteen parantamiseksi? Meillä on vuodesta 1955 lähtien korotettu lääketieteellisiin tiedekuntiin otettavien opiskelijoiden määrää aluksi 180:een vuodessa ja vuodesta 1958 lähtien 200:aan. Kun Oulun yliopisto saattoi syksyllä 1960 ottaa ensimmäiset ylioppilaat lääketiedettä opiskelemaan, nousi lääkäriksi opiskelemaan kotimaisissa yliopistoissamme vuosittain otettavien lukumäärä 250:een. Nyt on Helsingin yliopiston lääketieteellinen tiedekunta päättänyt ottaa syksyllä 1961 lisää 30 opiskelijaa ja vuoden 1962 alusta niinikään 30 opiskelijaa, joten yhteensä maamme lääketieteellisiin tiedekuntiin voidaan ottaa vuosittain vuodesta 1962 lähtien 310 opiskelijaa. Edelleen on pidettävä mielessä, että me olemme syksysțä 1960 lähtien voineet lähettää opiskelijoita ulkomaisiin lääketieteellisiin tiedekuntiin. Vuoden 1960 aikana heidän määränsä ylitti 50:n ja näyttää siltä, että vuonna 1961 voidaan ulkomaille lähettää noin 75 opiskelijaa. Jos niinä neljänä vuonna, jotka lain mukaan vielä ovat käytettävissä, onnistutaan lähettämään vuosittain 75 opiskelijaa ulkomaisiin yliopistoihin, merkitsee se sitä, että meillä vuodesta 1962 lähtien alkaa vuosittain opiskella lääketiedettä 385 opiskelijaa.

Edellä selostettu opiskelutahti merkitsee sitä, että meillä vuonna 1970 , siis 9 vuo- 
Taulu 2. Arviointi lääkäritiheyden kehityksestä Suomessa vuoteen 1980 mennessä.

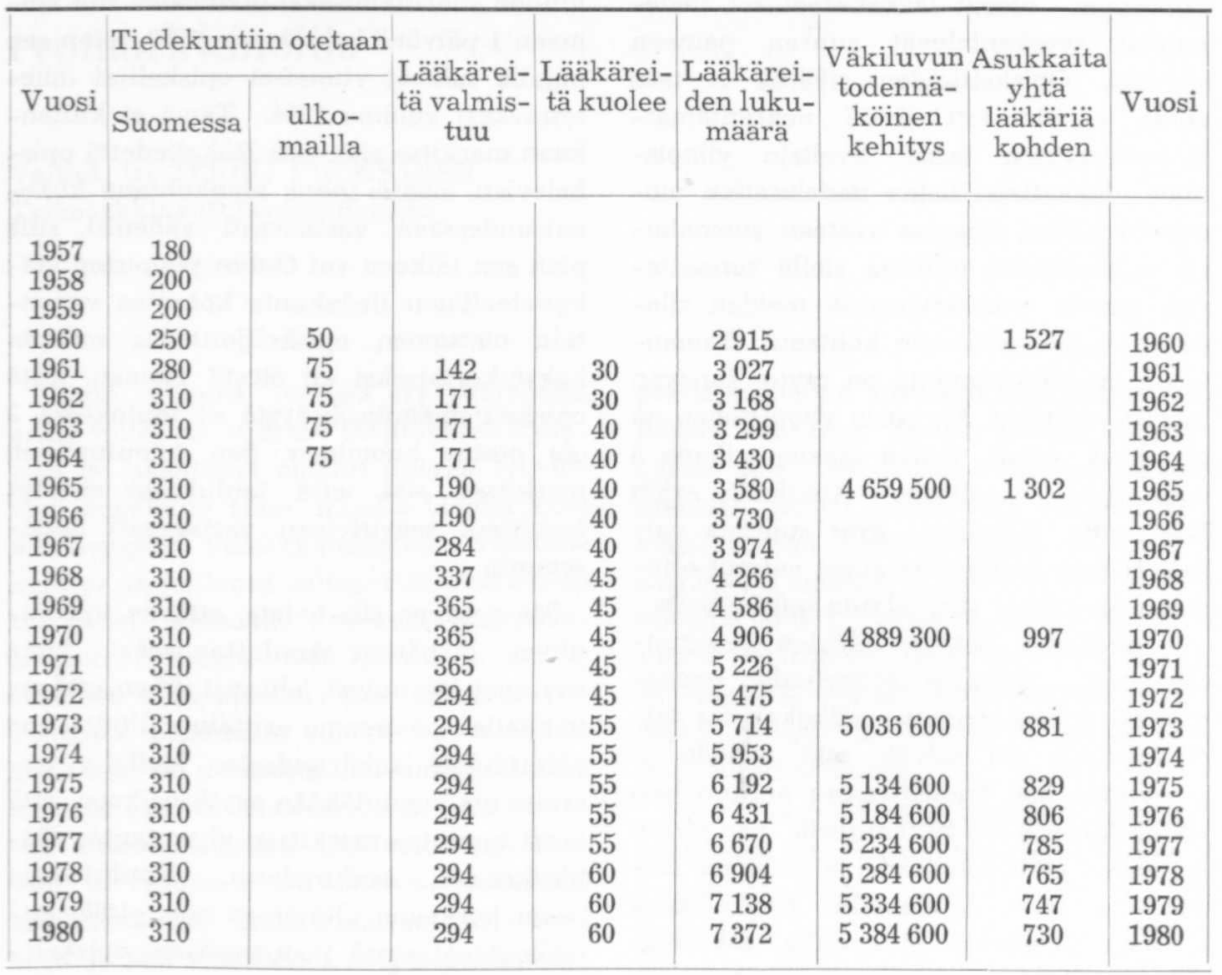

den kuluttua, olisi 1 lääkäri noin 1000 asukasta kohden (taulu 2). Tällöin on tietysti otettu huomioon väestön lisäys. Ja mitä kehityksen jatkumiseen tulee, nousee meidän lääkärimäärämme lähes kaksinkertaiseksi vuoteen 1973 mennessä, jolloin meillä on 1 lääkäri noin 880 asukasta kohden. Jos edelleen pidetään yllä samaa opiskelutahtia ja otetaan huomioon väestön lisäys, joka vuoteen 1980 mennessä tilastollisen päätoimiston laskelmien mukaan nousee 5384600 :aan, tulisi meillä vuonna 1980 olemaan 1 lääkäri 730 asukasta kohden. Tällöin ei lääkäripulasta varsinaisessa mielessä enää voitane puhua.

Näitä laskelmia suoritettaessa on otettu huomioon opiskelijoiden keskuudessa tapahtuva kato, joka on kokemusperäisesti arvioitu $5 \%: \mathrm{ksi}$, samoin on tietysti otettu huomioon kuoleman kautta poistuvat lääkärit. Sen sijaan tilastossa ei ole kiinnitetty huomiota eläkeiän sivuuttaneisiin lääkäreihin, vaan tilasto koskee lääkärikuntaa kokonaisuudessaan.

Niinkuin edellä olevasta selostuksesta käy ilmi, alkaa meidän lääkäritilanteessamme tuntua helpotusta varsinaisesti vasta vuonna 1970 ja sen jälkeen. Jossain määrin sitä voinee todeta jo aikaisemminkin, sillä esim. vuonna 1965 on meillä nykyisellä koulutustahdilla jo 1 lääkäri 1300 asukasta kohden, mikä merkitsee huomattavasti suurempaa lääkäritiheyttä kuin nykyinen.

Edellä esitetyssä lääkäritilanteen kehityksessä on tietysti eräitä epävarmoja tekijöitä, joihin mm. kuuluu kysymys siitä, miten runsaasti ulkomaisissa yliopistoissa voidaan saada koulutetuksi lääkäreitä. Tässä suhteessa tuottaa suuria vaikeuksia se, että lääkäripula ei ole vain yksinomaan meitä koskeva kysymys, vaan se on monissa osissa maailmaa vallitseva ilmiö, ja ns. kehitysmaiden tarve siinä suhteessa on 
mittaamaton. Tästä syystä eri puolilla Eurooppaa olevat lääketieteelliset tiedekunnat työskentelevät suuren paineen alaisina. Opiskelijoiden määrää ei taas voida rajattomasti lisätä vaarantamatta koulutuksen tasoa. Sveitsin yliopistojen lääketieteellisten tiedekuntien menettely niiden ottaessa vastaan suomalaisia opiskelijoita, osoittaa siellä tunnettavan suurta ymmärtämystä meidän tilapäisiä vaikeuksiamme kohtaan. Samanlaista myötämielisyyttä on myös Tanskan taholta osoitettu, Aarhusin yliopistohan on luvannut ottaa viiden vuoden aikana 5 opiskelijaa vuosittain. Niinikään eräät Englannin yliopistot ovat suurista vaikeuksistaan huolimatta olleet valmiit ottamaan muutamia suomalaisia opiskelijoita.

Ulkomaisten lääketieteellisten tiedekuntien apuun maamme lääkäripulan poistamiseksi on turvauduttu väliaikaisena toimenpiteenä. On selvää, että meidän on pystyttävä itse huolehtimaan normaalisen lääkäritarpeen tyydyttämisestä. Sen sijaan voitaneen pitää asiallisena ja maamme sairaan- ja terveydenhoidolle hyödyllisenä sellaista järjestelyä, että osalle lääkäreistämme jatkuvasti tarjoutuisi mahdollisuus saada opetusta myös ulkomaisissa yliopistoissa. Täydellinen omaan kuoreen sulkeutuminen ei tässäkään asiassa ole maallemme, ei sen sairaanhoidolle enempää kuin sen lääketieteelliselle tutkimuksellekaan, eduksi.

Tarkasteltaessa nyt käyntiin pannun lääkärikoulutuksen jatkuvaa kehitystä mainittiin, että ulkomainen koulutus on tarkoitettu vain viideksi vuodeksi. Laki opintolainan myöntämisestä lääkärintutkinnon suorittamiseksi ulkomailla tuli voimaan 1 päivänä heinäkuuta 1960 , joten sen nojalla tulevat viimeiset opiskelijat lähetettäväksi vuonna 1964. Tämä ei kuitenkaan merkitse sitä, että lääketiedettä opiskelevien määrä tuona ajankohtana kokonaisuudessaan vastaavasti vähenisi, sillä pian sen jälkeen voi Oulun yliopiston lääketieteellinen tiedekunta kohottaa vuosittain otettavien opiskelijoittensa määrän kaksinkertaiseksi eli 50:stä 100:aan. Tätä opiskelijamäärän lisäystä ei taulukossa 2 ole otettu huomioon. Sen toteutuminen merkitsee sitä, että taulukossa esitetyt tavoitteet saavutetaan vastaavasti aikaisemmin.

Me voimme siis todeta, että ne toimenpiteet lääkärien kouluttamiseksi, jotka nyt ovat käynnissä, johtavat siihen, että me vähitellen pääsemme erittäin valitettavana pidettävästä lääkäripulasta. Meillä ei toisaalta ole pienintäkään syytä pelkoon, että tämä koulutus merkitsisi ylituotantoa lääkärikunnan keskuudessa. Koulutuksen tason korkeana pitäminen edellyttää, että lääketieteellisessä tiedekunnassa opiskelevien määrä on oikeassa suhteessa koulutusmahdollisuuksiin. Me olemme siinä suhteessa jo saavuttaneet Helsingin ja Turun yliopistojen lääketieteellisissä tiedekunnissa ylärajan. Jos parinkymmenen vuoden kuluttua havaitaan lääkärimäärä valtakunnassa riittäväksi, voidaan suurella tyydytyksellä vain todeta, että opiskelijoiden määrää eri tiedekunnissa voidaan pienentää ja siten nostaa koulutuksen tasoa. 